\title{
Iznenadna srčana smrt
}

\author{
Vladan Vukčević \\ Klinika za kardiologiju, Klinički centar Srbije; Medicinski fakultet, Univerzitet u Beogradu
}

I znenadna srčana smrt (ISS) se definiše kao prirodna smrt čiji je uzrok srčano oboljenje, a koja se manifestuje gubitkom svesti nastalim unutar jednog sata od početka akutnih promena u fukciji kardiovaskularnog sistema. ${ }^{1} \mathrm{U}$ ovoj definiciji se nalaze bitne karakteristike sindroma ISS: ona je prirodna, brza i neočekivana. Kako je neposredni uzrok srčanog zastoja nagla promena funkcionisanja kardiovaskularnog sistema koja je nespojiva sa očuvanjem svesti zbog naglog prekida snabdevanja krvlju centralnog nervnog sistema, veoma je važno da se u definiciji naglasi kratak vremenski interval između početka poremećaja odgovornog za srčani zastoj i nastanka gubitka svesti. Smatra se da je incidenca ISS 0.1-0.2\% godišnje. Epidemiološke studije su registrovale češću pojavu ISS u ranim jutarnjim časovima, češće ponedeljkom nego ostalim danima u nedelji i češće tokom zimskih meseci. ${ }^{2}$ Koronarna bolest je odgovorna za $80-85 \%$ svih slučajeva ISS. Dok je ateroskleroza primarni poremećaj kod ljudi srednje i starije živtone dobi, kod dece i mladih osoba uzrok srčanog zastoja mogu biti i anomalije koronarnih arterija, posebno anomalno ishodište leve koronarne arterije iz pulmonalne arterije ili iz desnog koronarog sinusa. ISS je prva klinička manifestacija bolesti kod 20-25\% koronarnih bolesnika, a prethodni infarkt miokarda se nalazi čak kod $75 \%$ bolesnika koji su umrli ili preživeli ISS. ${ }^{1}$

Električni mehanizmi srčanog zastoja u većini slučajeva su tahiaritmični [ventrikularna fibrilacija (VF) i produžena ventrikularna tahikardija (VT) koja progredira u VF) ali mogu biti i bradiaritmični-asistolni (asistola i elektromehanička disocijacija)]. Bolesnici kod kojih se u trenutku prvog medicinskog kontakta registruje elektromehanička disocijacija imaju najveći mortalitet.

Brojni su pokušaji da se otkriju markeri za povećanu sklonost ka ISS kod koronarnih bolesnika. Najpopularnija je niska ejekciona frakcija (EF), ali su njena slaba senzitivnost i nemogućnost da predvidi pojavu ISS kod velikog broja bolesnika kod kojih je ISS prva manifestacija koronarne bolesti ohrabrili istraživače da traže nove markere. Korisni su podaci koji se mogu dobiti čitanjem elektrokardiograma (alternans T talasa, trajanje QT intervala, QT disperzija) i analizom testa fizičkim opterećenjem (ubrzan puls u mirovanju, slab porast frekvence tokom napora i nedovoljno usporenje frekvence tokom prvog minuta odmora). Pojava većeg broja ekstrasistola na 24-časovnom Holteru EKG-a nakon preležanog srčanog udara (kao granična vrednost se uzima 10 i više ventrikualnih ekstrasistola na sat) i kratkotrajna VT uzimaju se takođe kao prediktori za pojavu ISS, ali njihovu vrednost pojedini autori dovode u pitanje.

Terapija ISS se rukovodi sa dva osnovna principa: uspostaviti cirkulaciju što je pre moguće i obezbediti kontinuiranu podršku sistemu krvotoka dok se ne uspostavi njegova normalna spontana funkcija. Da bi se obezbedio prvi cilj mnoge zemlje, uključujući i našu, organizuju obuku paramedicinskog osoblja i obezbeđuju prisustvo automatskih eksternih defibrilatora na javnim mestima. Glavni prediktor preživljavanja osoba koje dožive srčani zastoj van bolnice jeste prisustvo svedoka tom događaju koji pozivaju službu hitne pomoći. ${ }^{3}$ Preporučuje se da nemedicinsko osoblje koristi gubitak svesti i izostanak disanja kao znake ISS. Nema studije koja je pokazala isplativnost palpiranja pulsa i njegov izostanak kao znaka ISS. ${ }^{4}$ Kardiopulonalnu reanimaciju treba započeti udarcem pesnice u grudni koš (na mesto spoja srednje i donje trećine grudne kosti). Ako ovaj manevar ne pomogne ne treba ga ponavljati već treba odmah pristupiti kardiopulmonaloj reanimaciji. Preživljavanje dostiže i do $35 \%$ ako se kardiopulmonalna reanimacija započne u prvom minutu od gubitka svesti. Elektrokonverzija je ključni postupak u reanimaciji i nju ne treba odlagati čak i kad uslovi za reanimaciju nisu idealni. Dalje bolničko lečenje ovih bolesnika je usmereno ka stabilizaciji poremećaja srčanog ritma, podršci cirkulaciji do njenog oporavka i obezbeđivanju mera za reverziju oštećenja organa koji su se javili kao posledica srčanog zastoja, pre svih oštećenja centralnog nervnog sistema. Mortalitet tokom te indeksne hospitalizacije se kreće oko $50 \%$, a uzroci smrti u bolnici najčešće nisu aritmogeni (30\% ljudi umire iz hemodinamskih razloga, a $60 \%$ od posledica poremećaja centralnog nervnog sistema). Anoksična encefalopatija je snažan prediktor intrahospitalnog mortaliteta, a strategija rane primene hipotermije u cilju smanjenja metaboličkih potreba i edema mozga ima korist u smanjenju mortaliteta. ${ }^{1}$

U primarnoj i sekundarnoj prevenciji pojave ISS na raspolaganju su nam četiri metode: medikamentna terapija (aniaritmici), hirurške metode za smanjenje aritmogenosti leve komore, ablacija aritmije preko katetera i ugradnja implantibilnog kardioverter defobrilatora (ICD). Nakon razočaravajućih rezultata CAST studije sa antiaritmicima I klase, pažnja je usmerena na amjodaron. Dve velike studije iz 1997. godine (EMIAT i CAMIAT) ${ }^{5,6}$ sa upotrebom amjodarona nakon preležanog srčanog udara od kojih je jedna zahtevala EF manju od $40 \%$, nisu pokazale smanjenje mortaliteta iako se lek pokazao korisnim u suzbijanju aritmija. Analiza po podgrupama je pokazala da 
kombinacija amjodarona sa beta blokatorima daje korist u smanjenju mortaliteta. ${ }^{7}$ Uporedo sa ovim studijama pojavile su se i studije sa ICD-om. Posebnu važnost ima MADIT II studija ${ }^{8}$ koja je pokazala značajno smanjenje mortaliteta kod bolesnika sa prethodnim infarktom miokarda i $\mathrm{EF} \leq 30 \%$ u odnosu na konvencionalnu terapiju antiaritmičnim lekovima. ICD je jedini vid prevencije i lečenja koji ima dokazanu efikasnost da smanji pojavu ISS i totalnog mortaliteta. U primarnoj prevenciji smanjuje rizik od ISS kod dve grupe bolesnika: onih sa EF $\leq 40 \%$ koji imaju kratkotrajnu VT i produženu monomorfnu VT inudkovanu na elektrofiziološkim testovima, kao i kod onih sa EF $\leq 30 \%$ kao posledica srčanog udara. Ugradnju ICD-a treba odložiti 40 dana od akutnog koronarnog događaja, a u slučaju da se radi o revaskularizaciji miokarda, potrebu za njegovom ugradnjom reevaluirati 3 meseca nakon urađene revaskularizacije.

\section{Literatura}

1. Myerburg RJ, Castellanos A. Cardiac arrest and sudden cardiac death. U knjizi: Braunwald's Heart Diseases. A Textbook of Cardiovascular Medicine. Philadelphia: Saunders Elsevier, 2008: 933-74.
2. Arntz HR, Willich SN, Schreiber C, et al. Diurnal, weekly and seasonal variation of sudden death. Population-based analysis of 24,061 consecutive cases. Eur Heart J 2000:21;315-21.

3. Ewy GA. Do modifications of the American Heart Association guidelines improve survival of patients with out-of-hospital cardiac arrest? Circulation 2009; 119:2542-4.

4. Sayre MR, Koster RW, Botha M, et al. Part 5: Adult basic life support: 2010 International Consensus on Cardiopulmonary Resuscitation and Emergency Cardiovascular Care Science With Treatment Recommendations. Circulation 2010; 122:S298-S324.

5. Julian DG, Camm AJ, Frangin G, et al. Randomised trial of effect of amiodarone on mortality in patients with left ventricular disfunction after recent myocardial infarction: EMIAT. European Myocardial Infarct Amiodarone Trial Investigators. Lancet 1997;349:667-76.

6. Cairns JA, Connolly SJ, Roberts R, Gent M. Randomised trial on outcome after myocardial infarction in patients with frequent or repetitive ventricular premature depolarisations: CAMIAT. Canadian Amiodarone Myocardial Infarction Arrhythmia Trial Inestigators. Lancet 1997;349:675-86.

7. Boutitie F, Boissel JP, Connolly JP, et al. Amiodarone interaction with beta-blockers: analysis of the merged EMIAT (European Myocardial Infarct Amiodarone Trial) and CAMIAT(Canadian Amiodarone Myocardial Infarction Arrhythmia Trial) databases. Circulation 1999;99:2268-76.

8. Moss AJ, Zareba W, Hall WJ, et al. Prophylactic implantation of a defibrilator in patients with myocardial infarction and reduced ejection fraction. N Engl J Med 2002;346:877-85. 